\title{
Effects of Furosemide on Body Water Compartments in Infants with Bronchopulmonary Dysplasia ${ }^{1}$
}

\author{
B. HELEN O'DONOVAN AND EDWARD F. BELL
}

Department of Pediatrics, University of Iowa, Iowa City, Iowa 52242

\begin{abstract}
We studied the effects of a single dose of intravenous furosemide on the body water compartments of nine infants with bronchopulmonary dysplasia. We measured total body water, extracellular water, and plasma volume using deuterium oxide, sodium bromide, and Evans blue dye, respectively. From the results of these measurements, we calculated cell water, interstitial water, red cell volume, and total blood volume. We performed these measurements on the first day of the study and again $28 \mathrm{~h}$ later, $4 \mathrm{~h}$ after an intravenous dose of furosemide $(1 \mathrm{mg} / \mathrm{kg})$. All infants had a brisk diuresis in the first hour after the dose, but urine output was no greater during the 24-h period after the dose than during the preceding $24-h$ period. Total body water, extracellular water, and interstitial water were significantly decreased $\mathbf{4 h}$ after furosemide. There was no change in plasma volume, red cell volume, or total blood volume (Pediatr Res 26: 121-124, 1989)
\end{abstract}

\section{Abbreviations}

BPD, bronchopulmonary dysplasia

TBW, total body water

IW, interstitial water

ECW, extracellular water

PV, plasma volume

CBS, corrected bromide space

$\mathrm{Br}$, bromide

IW, interstitial water

$\mathrm{BV}$, blood volume

$\mathrm{D}_{2} \mathrm{O}$, deuterium oxide

ICW, intracellular water

Hct, hematocrit

$\mathrm{RCV}$, red cell volume

OD, optical density

Infants with BPD have interstitial pulmonary edema (1). Furosemide has been shown to improve lung function and speed recovery of these infants (2-4), but the mechanism of these effects is not known. Although the water mobilized and excreted after furosemide administration is assumed to be extracellular in origin, little is known about the effects of furosemide on specific body water compartments in health and disease.

Received January 12, 1989; accepted April 20, 1989.

Correspondence and reprint requests Edward F. Bell, M.D., Department of Pediatrics, University of Iowa, lowa City, IA 52242.

Supported by Grants HD16974, HD07578, and RR00059 from the National Institutes of Health. B.H.O. was a fellow supported by NIH Training Grant HD07287.

1 Presented at the Annual Meeting of the American Pediatric Society and the Society for Pediatric Research, Washington, D.C., May 3, 1988
Studies in adults with pulmonary edema (5-7) have shown variable effects of furosemide on plasma volume. Davidor et al. (5) measured plasma vol in patients with refractory edema $2 \mathrm{~h}$ after an intravenous dose of furosemide. These patients had a mean decrease of $25 \%$ in plasma volume. Figueros and Weil (6) found that the plasma volume of adults with acute cardiogenic pulmonary edema was lower than normal before therapy but rose after treatment with furosemide, oxygen, and morphine. Schuster et al. (7) measured blood volume in 21 patients with pulmonary edema who had either normal or decreased renal function. The patients who had normal renal function, as indicated by a good diuresis, had no change in plasma volume 4 to $6 \mathrm{~h}$ after a single intravenous dose of furosemide. Patients who did not have a good diuresis had a rise in plasma volume.

There have been no similar studies in infants. Infants with BPD are often fluid restricted with the hope that this will reduce pulmonary edema. It would be of practical value to know whether furosemide causes a decrease in plasma volume in these infants, because hypovolumeemia might compromise organ perfusion and activate the compensatory mechanisms that stimulate water and sodium retention. Our study was undertaken to assess the effects of a single intravenous dose of furosemide on the plasma volume and other body water compartments of infants with BPD.

\section{MATERIALS AND METHODS}

Nine infants with BPD were studied (Table 1). Their birth wt ranged from 0.57 to $2.24 \mathrm{~kg}$ (median $0.74 \mathrm{~kg}$ ), with gestational ages from 24 to $36 \mathrm{wk}$ (median $27 \mathrm{wk}$ ). At the time of study their body wt ranged from 0.92 to $3.98 \mathrm{~kg}$ (median $2.12 \mathrm{~kg}$ ); their ages were from 31 to $130 \mathrm{~d}$ (median $65 \mathrm{~d}$ ). BPD was diagnosed if an infant still required supplemental oxygen or mechanically assisted ventilation beyond $21 \mathrm{~d}$ of age and had typical changes of BPD on chest $x$-ray. Infants who were receiving chronic diuretic therapy or who had received any furosemide within the previous $48 \mathrm{~h}$ were excluded, as were infants with abnormal renal function or major congenital anomalies. The study was approved by the Human Subjects Review Committee of the University of Iowa, and informed consent was obtained from the parents of each subject.

The experimental period lasted $52 \mathrm{~h}$. The rate of fluid intake was not standardized among infants, but in each case the intravenous infusion rate or enteral feeding volume was not changed during the 52-h experimental period. At the beginning of the first day, TBW, ECW, and PV were measured as the dilution volume of $\mathrm{D}_{2} \mathrm{O}$, sodium bromide, and Evans blue dye, respectively. Then $24 \mathrm{~h}$ later a single $1-\mathrm{mg} / \mathrm{kg}$ dose of furosemide was given intravenously. Four $\mathrm{h}$ after this dose, the body water compartments were measured again; $4 \mathrm{~h}$ was chosen because most of the diuresis resulting from furosemide was expected within that period $(8,9)$. The $\mathrm{D}_{2} \mathrm{O}$ and Evans blue dye were 
administered $4 \mathrm{~h}$ after the furosemide. The sodium $\mathrm{Br}$ was given $1 \mathrm{~h}$ after the furosemide, allowing measurement of $\mathrm{Br}$ space $3 \mathrm{~h}$ later, at the same time as the determinations of deuterium space and PV. Before each administration of $\mathrm{D}_{2} \mathrm{O}$, sodium $\mathrm{Br}$, and Evans blue dye, baseline urine, serum, and plasma samples were collected. The infant was weighed before the administration of marker substances on the first day.

Deuterium oxide (99.8\%, MSD Isotopes, Montreal, PQ) was administered intragastrically in a dose of $1 \mathrm{~g} / \mathrm{kg}$ except for infant 3 , who received this dose intravenously. If a gastric tube was used, the deuterium was flushed through the tube using $3 \mathrm{~mL}$ of formula or milk; the regular feeding was then given 20 min later through the same tube. If the intravenous route was used, the stopcock and tubing were flushed with sterile normal saline. The syringe containing the $\mathrm{D}_{2} \mathrm{O}$ was weighed to the nearest $0.0001 \mathrm{~g}$ before and after the dose was given. Urine samples were collected by positioning the infant on a mattress over a recessed collection vessel. We used a modified colostomy bag to collect urine from the larger infants who were more active. The volume and time of each urine sample were recorded. The last urine collected before the administration of $\mathrm{D}_{2} \mathrm{O}$ and aliquots from each spontaneous voiding between 8 and $24 \mathrm{~h}$ after administration were saved for analysis of deuterium oxide enrichment. $\mathrm{D}_{2} \mathrm{O}$ enrichment in the urine samples was measured using nuclear magnetic resonance spectroscopy (10). After plotting the logarithm of $\mathrm{D}_{2} \mathrm{O}$ enrichment in urine versus time, the TBW at the time of administration of the $\mathrm{D}_{2} \mathrm{O}$ was calculated by extrapolating the urine enrichment back to 0 time using linear regression analysis. The formula for calculation of TBW volume $(\mathrm{mL})$ is shown below.

$$
\mathrm{TBW}=\frac{\mathrm{D}_{2} \mathrm{O} \text { dose } \times 18.02 \times 0.998 \times 100}{\mathrm{APE} \mathrm{D}_{2} \mathrm{O} \times 20.02 \times 1.015 \times 0.993}
$$

where $\mathrm{D}_{2} \mathrm{O}$ dose is the wt $(\mathrm{g})$ of the $\mathrm{D}_{2} \mathrm{O}$ administered, 18.02 is the mol wt of water, 0.998 is the purity of the $\mathrm{D}_{2} \mathrm{O}$ administered, 100 is a factor to convert atom percent to atomic ratio, APE $\mathrm{D}_{2} \mathrm{O}$ is the rise in atom percent excess from predosing to the 0 -h extrapolated value, 20.02 is the mol wt of $\mathrm{D}_{2} \mathrm{O}, 1.015$ is the correction for deuterium distributed into nonaqueous tissues (11-14), and 0.993 is the specific gravity of water at body temperature.

At the time of $\mathrm{D}_{2} \mathrm{O}$ administration on each day of the experiment, sodium $\mathrm{Br}$ was also administered either by gastric feeding tube or, in infant 3, intravenously (after the baseline serum sample was drawn). Oral and intravenous administration of sodium $\mathrm{Br}$ have been shown to yield similar estimates of ECW in adults (15). The dose used was $4.5 \mathrm{~mL} / \mathrm{kg}$ of a $0.333 \mathrm{M}$ solution of sodium $\mathrm{Br}(1.5 \mathrm{mmol} / \mathrm{kg})$. The exact dose given was determined by weighing the syringe to the nearest $0.0001 \mathrm{~g}$ before and after administration. Three $\mathrm{h}$ later, a single serum sample was taken for bromide analysis. From the time of administration of the dose to the second serum sample, all voided urine was pooled for determination of $\mathrm{Br}$ excretion. The excreted $\mathrm{Br}$ was then subtracted from the dose injected. Br was analyzed using a spectrophotometric method based on the reaction of $\mathrm{Br}$ with fluorescein (16). The ECW was assumed to be equal to the CBS. The CBS (mL) was calculated using the formula below (17).

$$
\mathrm{CBS}=\frac{\mathrm{Br} \text { dose }}{[\mathrm{Br}]_{\mathrm{s}}} \times 0.90 \times 0.95 \times 0.94 \times 1000
$$

where $\mathrm{Br}$ dose is the amount (mmol) of $\mathrm{Br}$ given minus the amount excreted in the urine from 0 to $3 \mathrm{~h},[\mathrm{Br}]_{\mathrm{s}}$ is the serum $\mathrm{Br}$ concentration (mM), 0.90 is the fraction of the dose assumed to remain extracellular, 0.95 is the correction for the Donnan equilibrium, 0.94 is the assumed water content in serum, and 1000 is the factor to convert liters to $\mathrm{mL}$. ECW.

CW $(\mathrm{mL})$ was calculated as the difference between TBW and

$$
\mathrm{ICW}=\mathrm{TBW}-\mathrm{ECW}
$$

Plasma volume was determined as the volume of distribution of Evans blue dye (T-1824) administered intravenously. The dye concentration was measured spectrophotometrically using the method of Nielsen and Nielsen (18) as adapted by Parving et al. (19) and Linderkamp et al. (20). The original method (18) requires that the linear relationship between the negative logarithm of the absorbance of undyed plasma at the wave lengths 620 and $740 \mathrm{~nm}$ be established for the spectrophotometer being used. Inasmuch as Evans blue dye has its highest absorbance at $620 \mathrm{~nm}$ and no absorbance at $740 \mathrm{~nm}$, the blank OD for each plasma sample can be calculated from the absorbance at 740 $\mathrm{nm}$. We measured these absorbance values for 14 plasma samples from normal infants. The actual absorbance values rather than negative logarithms were plotted against each other $(19,20)$. The resulting relation is described by the following equation.

$$
\mathrm{OD}_{620}=1.40 \mathrm{OD}_{740}+0.010
$$

The OD of Evans blue dye at $620 \mathrm{~nm}$ for each plasma sample was then calculated using the following formula.

$$
\left.\mathrm{OD}_{620}(\text { corrected })=\mathrm{OD}_{620} \text { (measured }\right)-\left[1.40 \mathrm{OD}_{740}+0.010\right]
$$

where $\mathrm{OD}_{620}$ (corrected) is the sample OD at $620 \mathrm{~nm}$ (for Evans blue dye alone), $\mathrm{OD}_{620}$ (measured) is the sample $\mathrm{OD}$ at $620 \mathrm{~nm}$ (for dye and plasma) as experimentally determined, and $\mathrm{OD}_{740}$ is the sample OD at $740 \mathrm{~nm}$.

\begin{tabular}{|c|c|c|c|c|c|c|}
\hline \multirow[b]{2}{*}{ Subject } & \multirow{2}{*}{$\begin{array}{c}\text { Gestational } \\
\text { age } \\
\text { (wk) }\end{array}$} & \multirow{2}{*}{$\begin{array}{l}\text { Postnatal } \\
\text { age } \\
\text { (d) }\end{array}$} & \multicolumn{2}{|c|}{ Intake } & \multicolumn{2}{|c|}{ Output } \\
\hline & & & $\begin{array}{l}\text { Before } \\
\text { furosemide } \\
(\mathrm{mI}\end{array}$ & $\begin{array}{l}\text { After } \\
\text { furosemide } \\
\left.\mathrm{h}^{-1}\right)\end{array}$ & $\begin{array}{c}\text { Before } \\
\text { furosemide } \\
(\mathrm{mI}\end{array}$ & $\begin{array}{l}\text { After } \\
\text { furosemide } \\
\left.h^{-1}\right)\end{array}$ \\
\hline 1 & 24 & 46 & 6.9 & 6.9 & 3.6 & 5.1 \\
\hline 2 & 31 & 31 & 5.3 & 4.6 & 4.0 & 2.7 \\
\hline 3 & 26 & 100 & 5.2 & 5.2 & 1.7 & 3.2 \\
\hline 4 & 30 & 65 & 5.7 & 5.8 & 3.6 & 3.4 \\
\hline 5 & 27 & 67 & 6.5 & 6.4 & 3.9 & 4.1 \\
\hline 6 & 26 & 130 & 5.7 & 6.3 & 2.3 & 3.1 \\
\hline 7 & 25 & 60 & 6.8 & 6.3 & 3.8 & 4.2 \\
\hline 8 & 30 & 52 & 7.8 & 8.0 & 4.6 & 4.9 \\
\hline 9 & 36 & 82 & 5.7 & 6.0 & 1.5 & 1.5 \\
\hline $\begin{array}{l}\text { Mean } \\
\text { (SD) }\end{array}$ & $\begin{array}{l}28 \\
(4)\end{array}$ & $\begin{array}{c}70 \\
(30)\end{array}$ & $\begin{array}{c}6.2 \\
(0.9)\end{array}$ & $\begin{array}{c}6.2 \\
(1.0)\end{array}$ & $\begin{array}{c}3.2 \\
(1.1)\end{array}$ & $\begin{array}{c}3.6 \\
(1.1)\end{array}$ \\
\hline
\end{tabular}

A blank plasma sample was collected before administration of Evans blue dye on days 1 and 2 . Evans blue dye $(4.5 \mathrm{mg} / \mathrm{mL}$, Harvey Laboratories, Philadelphia, PA) is packaged in $5-\mathrm{mL}$

Table 1. 24-h water balance before and after furosemide administration 
vials for injection. We diluted one vial with normal saline $1: 5$ ( $\mathrm{vol} / \mathrm{vol}$ resulting concentration $0.75 \mathrm{mg} / \mathrm{mL}$ ) and gave $0.5 \mathrm{~mL} /$ $\mathrm{kg}$ intravenously at 0 time on the first day. The precise dose given was determined by weighing the syringe to the nearest $0.0001 \mathrm{~g}$ before and after administration. Ten min later a second sample was taken. Four hours after the dose of furosemide on the secorid day, Evans blue dye was given again in a similar dose with blood samples taken before and $10 \mathrm{~min}$ after administration. Each injectate was diluted 1:100 vol/vol with distilled water; the $\mathrm{OD}$ at $620 \mathrm{~nm}$ and the specific gravity of each resulting solution were measured.

PV $(\mathrm{mL})$ was calculated using the following formula.

$$
\mathrm{PV}=\frac{\text { injectate } \mathrm{OD}_{620} \times 100 \times \text { injectate dose }}{\text { sample } \mathrm{OD}_{620}(\text { corrected }) \times \text { injectate } \mathrm{SG}}
$$

where injectate $\mathrm{OD}_{620}$ is the optical density at $620 \mathrm{~nm}$ of the diluted injectate, 100 is the dilution factor for the injectate, injectate dose is the wt $(\mathrm{g})$ of injectate administered, sample $\mathrm{OD}_{620}$ (corrected) is the difference between the OD at $620 \mathrm{~nm}$ (corrected as described above) of the 10-min sample and the predosing sample, and injectate $\mathrm{SG}$ is the specific gravity $(\mathrm{g} / \mathrm{mL})$ of the injectate. PV.

IW (mL) was calculated as the difference between ECW and

$$
\mathrm{IW}=\mathrm{ECW}-\mathrm{PV}
$$

At the time of each measurement of PV, a venous Hct was obtained. The total BV (mL) was then calculated.

$$
\mathrm{BM}=\frac{\mathrm{PV} \times 100}{100-(\mathrm{Hct} \times 0.98 \times 0.90)}
$$

where Hct is the venous Hct (\%), 0.98 is the correction for trapped plasma $(20)$, and 0.91 is the correction for whole body Hct (21).
Then RCV (mL) was calculated as follows.

$$
\mathrm{RCV}=\mathrm{BV}-\mathrm{PV}
$$

The body water compartments before and after furosemide administration were compared using the $t$ test for paired observations.

\section{RESULTS}

All infants had a significant diuresis during the first $4 \mathrm{~h}$ after administration of furosemide with the greatest diuresis occurring in the first hour. The mean diuresis during the first $4 \mathrm{~h}$ was 7.8 $\mathrm{mL} \cdot \mathrm{kg}^{-1} \cdot \mathrm{h}^{-1}$. The overall urine output for the $24 \mathrm{~h}$ after furosemide administration, however, was not different from the previous 24 -h period (Table 1 ).

Tables 2 and 3 illustrate the values for body water compartments before and $4 \mathrm{~h}$ after $1 \mathrm{mg} / \mathrm{kg}$ of intravenous furosemide. The results in Tables 2 and 3 are expressed in $\mathrm{mL}$ and $\mathrm{mL} / \mathrm{kg}$ initial body wt, respectively. There was a significant decrease in TBW, ECW, and IW. Although intracellular water tended to increase, this change was not significant. PV, BV, and RCV were unchanged.

Serum $\mathrm{Br}$ concentrations $3 \mathrm{~h}$ after administration varied from 1.35 to $4.81 \mathrm{mM}$ on d 1 , with a mean of $2.52 \mathrm{mM}$ (SD 1.12). Serum concentrations $3 \mathrm{~h}$ after dosing on $\mathrm{d} 2$ ranged from 3.74 to $7.13 \mathrm{mM}$ with a mean of $5.31 \mathrm{mM}$ (SD 1.05). No adverse effects of $D_{2} \mathrm{O}, \mathrm{Br}$, or Evans blue dye were recognized in any of the infants.

\section{DISCUSSION}

The measured diuresis during the $4 \mathrm{~h}$ between furosemide administration and body water measurement was, on average, $7.8 \mathrm{~mL} \cdot \mathrm{kg}^{-1} \cdot \mathrm{h}^{-1}$, or $31 \mathrm{~mL} / \mathrm{kg}$. This value is considerably less than the mean decrease in $\mathrm{TBW}$ of $87 \mathrm{~mL} / \mathrm{kg}$, suggesting error

\begin{tabular}{|c|c|c|c|c|c|c|c|c|c|}
\hline Subject & & $\mathrm{Wt}(\mathrm{kg})$ & TBW & ICW & $\mathrm{ECW}$ & IW & PV & $\mathrm{RCV}$ & BV \\
\hline \multirow[t]{2}{*}{1} & Before furosemide & 0.92 & 701 & 325 & 376 & 313 & 63 & 21 & 84 \\
\hline & After furosemide & 631 & 339 & 292 & 234 & 58 & 21 & 79 & \\
\hline \multirow[t]{2}{*}{2} & & 1.47 & 1300 & & & & 110 & 45 & 155 \\
\hline & & & 1081 & & & & 105 & 45 & 150 \\
\hline \multirow[t]{2}{*}{3} & & 2.06 & 1707 & 592 & 1115 & 977 & 138 & 60 & 198 \\
\hline & & & 1466 & 542 & 924 & 783 & 141 & 55 & 196 \\
\hline \multirow[t]{2}{*}{4} & & 2.34 & 1732 & 612 & 1120 & 957 & 163 & 58 & 221 \\
\hline & & & 1845 & 1338 & 507 & 339 & 168 & 63 & 231 \\
\hline \multirow[t]{2}{*}{5} & & 2.28 & 1817 & & & & 166 & 55 & 221 \\
\hline & & & 1374 & & & & 162 & 47 & 209 \\
\hline \multirow[t]{2}{*}{6} & & 3.98 & 3290 & 1386 & 1904 & 1675 & 229 & 69 & 298 \\
\hline & & & 2662 & 1397 & 1265 & 1086 & 179 & 52 & 231 \\
\hline \multirow[t]{2}{*}{7} & & 1.50 & 1176 & 430 & 746 & 635 & 111 & 54 & 165 \\
\hline & & & 1138 & 670 & 468 & 346 & 122 & 60 & 182 \\
\hline \multirow[t]{2}{*}{8} & & 2.12 & 1664 & 991 & 673 & 505 & 168 & 60 & 228 \\
\hline & & & 1445 & 779 & 666 & 500 & 166 & 61 & 227 \\
\hline \multirow[t]{2}{*}{9} & & 3.94 & 2759 & 1076 & 1683 & 1452 & 231 & 128 & 359 \\
\hline & & & 2739 & 1263 & 1476 & 1260 & 216 & 101 & 317 \\
\hline
\end{tabular}
in the determination of urine output or change in TBW or both. Unfortunately, body wt was not measured at the correct times

Table 2. Changes in body water compartments after intravenous furosemide, with compartments expressed in absolute volume

\footnotetext{
* Bromide space measurements were not done for subjects 2 and 5 .
} 
Table 3. Changes in body water compartments after intravenous furosemide, with compartments expressed in $\mathrm{mL} / \mathrm{kg}$ initial body $w t$

\begin{tabular}{|c|c|c|c|c|c|c|c|c|}
\hline \multicolumn{2}{|c|}{ Subject } & TBW & ICW & $\mathrm{ECW}$ & IW & PV & $\mathrm{RCV}$ & $\mathrm{BV}$ \\
\hline \multirow[t]{2}{*}{1} & Before furosemide & 762 & 353 & 409 & 340 & 68 & 23 & 91 \\
\hline & After furosemide & 686 & 368 & 317 & 254 & 63 & 23 & 86 \\
\hline \multirow[t]{2}{*}{2} & & 884 & & & & 75 & 31 & 105 \\
\hline & & 735 & & & & 71 & 31 & 102 \\
\hline \multirow[t]{2}{*}{3} & & 829 & 287 & 541 & 474 & 67 & 29 & 96 \\
\hline & & 712 & 263 & 449 & 380 & 68 & 27 & 95 \\
\hline \multirow[t]{2}{*}{4} & & 740 & 262 & 479 & 409 & 70 & 25 & 94 \\
\hline & & 788 & 572 & 217 & 145 & 72 & 27 & 99 \\
\hline \multirow[t]{2}{*}{5} & & 797 & & & & 73 & 24 & 97 \\
\hline & & 603 & & & & 71 & 21 & 92 \\
\hline \multirow[t]{2}{*}{6} & & 827 & 348 & 478 & 421 & 58 & 17 & 75 \\
\hline & & 669 & 351 & 310 & 273 & 45 & 13 & 58 \\
\hline \multirow[t]{2}{*}{7} & & 784 & 287 & 497 & 423 & 74 & 36 & 110 \\
\hline & & 759 & 447 & 312 & 231 & 81 & 40 & 121 \\
\hline \multirow[t]{2}{*}{8} & & 785 & 467 & 317 & 238 & 79 & 28 & 108 \\
\hline & & 682 & 367 & 314 & 236 & 78 & 29 & 107 \\
\hline \multirow{2}{*}{\multicolumn{2}{|c|}{9}} & 700 & 273 & 427 & 369 & 59 & 32 & 91 \\
\hline & & 695 & 321 & 375 & 320 & 55 & 26 & 80 \\
\hline \multirow{2}{*}{\multicolumn{2}{|c|}{$\begin{array}{l}\text { Mean before furosemide } \\
\text { (SD) }\end{array}$}} & 790 & 325 & 450 & 382 & 69 & 27 & 96 \\
\hline & & $(54)$ & (72) & (73) & (76) & (7) & (6) & (11) \\
\hline \multicolumn{2}{|c|}{ Mean after furosemide } & $\begin{array}{l}703^{*} \\
(54)\end{array}$ & $\begin{array}{c}384 \\
(100)\end{array}$ & $\begin{array}{c}329^{*} \\
(71)\end{array}$ & $\begin{array}{c}263^{*} \\
(74)\end{array}$ & $\begin{array}{c}67 \\
(11)\end{array}$ & 26 & $\begin{array}{c}93 \\
(18)\end{array}$ \\
\hline
\end{tabular}

* Significantly lower $(p<0.05)$ after furosemide.

during the study to help resolve this discrepancy. We speculate that our 4-h urine collections underestimated the cumulative diuresis up to the time of deuterium equilibration because of incomplete urine collection and because of urine that had already been cleared by the kidney but not yet voided before the $\mathrm{D}_{2} \mathrm{O}$ was administered. It is also possible that the magnitude of the change in TBW was overestimated; however, this seems less likely because the decrease in ECW (corrected $\mathrm{Br}$ space) was even greater than the decrease in TBW.

Furosemide has been previously shown to cause an increase in lung compliance and a decrease in airway resistance in infants with BPD (2). These effects were detectable $1 \mathrm{~h}$ after an intravenous dose of furosemide but did not persist. Patel et al. (22) also found clinical respiratory improvement that occurred only transiently $2 \mathrm{~h}$ after intravenous furosemide. The improvement in lung function produced by furosemide has been postulated to result from increased venous capacitance (23) or mobilization of excess IW from the lungs (24). Our finding of reduced whole body IW supports the latter hypothesis. Although we did not measure water compartments beyond $4 \mathrm{~h}$ after dosing, the 24-h water balance results suggest that the interstitial dehydration induced by furosemide probably lasted only a few hours; the same would presumably be true of the effects on lung function. Although it is possible that changes in intravascular volume occurred closer to the period of maximum diuresis at $1 \mathrm{~h}(8,9)$, we found no change in PV or calculated BV $4 \mathrm{~h}$ after the dose of furosemide.

The exact mechanism of fluid mobilization with furosemide is not known. It presumably results from the direct renal effects of furosemide, but it may also involve drug effects on the secretion of prolactin (25), vasopressin (26), or atrial natriuretic peptide. The mobilized water arises from the interstitial com- partment and is not limited to pulmonary IW. Although the increase in cell water was not statistically significant, our results suggest that there may also have been some movement of interstitial water into cells after furosemide administration.

Furosemide acutely decreased TBW and ECW in infants with BPD. This water was derived primarily from the interstitial space, presumably including lung IW. We postulate that the mobilization of IW observed in this study accounts, at least partly, for the acute effects of furosemide on lung function observed by other investigators (2-4).

\section{REFERENCES}

1. Northway WH, Rosan RC, Porter DY 1967 Pulmonary disease following respiratory therapy of hyaline membrane disease: bronchopulmonary dysplasia. N Engl J Med 276:357-368

2. Kao LC, Warburton D, Sargent CV, Platzker ACG, Keens TG 1983 Furosemide acutely decreases airways resistance in chronic bronchopulmonary dysplasia. J Pediatr 103:624-629

3. McCann EM, Lewis K, Deming DD, Donovan MJ, Brady JP 1985 Controlled trial of furosemide therapy in infants with chronic lung disease. J Pediatr 106:957-962

4. Engelhardt B, Elliott S, Hazinski TA 1986 Short- and long-term effects of furosemide on lung function in infants with bronchopulmonary dysplasia. $J$ Pediatr 109:1034-1039

5. Davidov M, Kakaviatos N, Finnerty FA Jr 1967 Intravenous administration of furosemide in heart failure. JAMA 200:120-125

6. Figueras J, Weil MH 1978 Blood volume prior to and following treatment of acute cardiogenic edema. Circulation 57:349-355

7. Schuster CJ, Weil MH, Besso J, Carpio M, Henning RJ 1984 Blood volume following diuresis by furosemide. Am J Med 76:585-592

8. Ross BS, Pollak A, Oh W 1978 The pharmacologic effects of furosemide therapy in the low-birth-weight infant. J Pediatr 92:149-152

9. Woo WC, Dupont C, Collinge J, Aranda JV 1978 Effects of furosemide in the newborn. Clin Pharmacol Ther 23:266-271

10. Rebouche CJ, Pearson GA, Serfass RE, Roth CW, Finley JW 1987 Evaluation of nuclear magnetic resonance spectroscopy for determination of deuterium abundance in body fluids: application to measurement of total-body water in human infants. Am J Clin Nutr 45:373-380

11. Schloerb PR, Friis-Hansen BJ, Edelman IS, Solomon AK, Moore FD 1950 The measurement of total body water in the human subject by deuterium oxide dilution with a consideration of the dynamics of deuterium distribution. J Clin Invest 29:1296-1310

12. Pinson EA 1952 Water exchanges and barriers as studied by the use of hydrogen isotopes. Physiol Rev 32:123-134

13. Friis-Hansen B 1971 Body composition during growth. In vivo measurements and biochemical data correlated to differential anatomical growth. Pediatrics 47:264-274

14. Culebras JM, Fitzpatrick GF, Brennan MF, Boyden CM, Moore FM 1977 Total body water and the exchangeable hydrogen. II. A review of comparative data from animals based on isotope dilution and desiccation, with a report of new data from the rat. Am J Physiol 232:R60-R65

15. Vaisman N, Pencharz PB, Koren G, Johnson JK 1987 Comparison of oral and intravenous administration of sodium bromide for extracellular water measurements. Am J Clin Nutr 46:1-4

16. Trapp SA, Bell EF 1989 An improved spectrophotometric bromide assay for the estimation of extracellular water volume. Clin Chim Acta 181:207-212

17. Bell EF, Ziegler EE, Forbes GB 1984 Letter to the editor. Pediatr Res 18:392393

18. Nielsen MH, Nielsen NC 1962 Spectrophotometric determination of Evans blue dye in plasma with individual correction for blank density by a modified Gaeblers method. Scand J Clin Lab Invest 14:605-617

19. Parving HH, Klebe JG, Ingomar CJ 1973 Simultaneous determination of plasma volume and transcapillary escape rate with ${ }^{131} \mathrm{I}$-labelled albumin and $\mathrm{T}-1824$ in the newborn. Acta Paediatr Scand 62:248-252

20. Linderkamp O, Mader T, Butenandt O, Riegel KP 1977 Plasma volume estimation in severely ill infants and children using a simplified Evans blue method. Eur J Pediatr 125:135-141

21. Bratteby LE 1967 Studies on erythro-kinetics in infancy. VIII. Mixing, disappearance rates and distribution volume of labelled erythrocytes and plasma proteins in early infancy. Acta Soc Med Upsal 72:249-271

22. Patel H, Yeh TF, Jain R, Pildes R 1985 Pulmonary and renal responses to furosemide in infants with stage III-IV bronchopulmonary dysplasia. Am J Dis Child 139:917-919

23. Dikshit K, Vyden JK, Forrester JS, Chatterjee K, Prakash R, Swan HJC 1973 Renal and extrarenal hemodynamic effects of furosemide in congestive heart failure after acute myocardial infarction. N Engl J Med 288:1087-1090

24. Bland RD, McMillan DD, Bressack MA 1978 Decreased pulmonary transvascular fluid filtration in awake newborn lambs after intravenous furosemide. $\mathrm{J}$ Clin Invest 62:601-609

25. Ertl T, Sulyok E, Bodis J, Csaba IF 1986 Plasma prolactin levels in full-term newborn infants with idiopathic edema: response to furosemide. Biol Neonate 49:15-20

26. Hazinski TA, Blalock WA, Engelhardt B 1988 Control of water balance in infants with bronchopulmonary dysplasia: role of endogenous vasopressin. Pediatr Res 23:86-88 